\title{
Evaluasi Beberapa Desain Pipa Mikropori Sebagai Sistem Aerasi Dalam Budidaya Ikan Lele (Clarias gariepinus) Intensif Berbasis Teknologi Bioflok
}

\section{Evaluation of Several Microporous Pipe Designs as Aeration System of Intensive Catfish (Clarias gariepinus) Culture Based on Biofloc Technology}

\author{
Sumitro ${ }^{1^{*}}$, Arfan Afandi $^{1}$, Kurniawan Wahyu Hidayat ${ }^{2}$ dan Rifqah Pratiwi ${ }^{3}$ \\ ${ }^{1}$ Program Studi Budidaya Perairan, Fakultas Perikanan dan Kelautan, Universitas Dayanu \\ Ikhsanuddin, Jl. Yos Sudarso No 43, Wolio, Baubau 93711, Indonesia \\ ${ }^{2}$ Program Studi Budidaya Ikan, Politeknik Kelautan dan Perikanan Pangandaran, Jl. Raya Babakan \\ KM 2, Pangandaran 46396, Indonesia \\ ${ }^{3}$ Program Studi Teknik Budidaya Perikanan, Politeknik Kelautan dan Perikanan Kupang, Jl. \\ Kampung Baru Pelabuhan Fery Bolok, Kupang Barat 85351, Indonesia
}

*Correspondence :

sumitro_m@yahoo.co.id

Received : 2019-11-13

Accepted : 2020-01-06

Kata Kunci :

Bioflok, Ikan Lele, Intensif, Pipa

Mikropori, Oksigen Terlarut,

Kinerja Produksi

Keywords :

Biofloc, Catfish, Intensive, Microporous Pipe, Dissolved Oxygen, Production Performance

\begin{abstract}
Abstrak
Teknologi bioflok dapat memperbaiki kualitas air di dalam media pemeliharaan ikan lele intensif dan bioflok juga dapat dimanfaatkan sebagai pakan bagi ikan. Namun adanya kebutuhan oksigen bakteri heterotrof yang sangat banyak pada teknologi bioflok mengakibatkan kandungan oksigen terlarut dalam media budidaya relatif rendah yang akhirnya dapat menghambat pertumbuhan ikan. Tujuan dari penelitian ini yaitu mengevaluasi beberapa desain pipa mikropori sebagai diffuser aerasi pada budidaya ikan lele intensif berbasis teknologi bioflok. Rancangan yang digunakan adalah rancangan acak lengkap (RAL) yang terdiri atas 4 perlakuan dan 3 ulangan. Pipa mikropori dibentuk dalam beberapa model pada sistem bioflok yaitu diffuser berbentuk linear (BFT L), diffuser bentuk sirkuler (BFT S), diffuser paralel (BFT P), serta batu aerasi sebagai kontrol (BFT K). Hasil penelitian menunjukkan pipa mikropori menghasilkan oksigen terlarut yang lebih tinggi pada kisaran 3-5,7 mg/l dibanding kontrol (batu aerasi). BFT L menghasilkan kelangsungan hidup ikan yang lebih tinggi sebesar 78,67\% $(\mathrm{P}<0,05)$. BFT L dan BFT S menunjukkan pertumbuhan harian tertinggi yaitu sebesar $6,80 \%$ hari $^{-1}$ dan $6,68 \%$ hari $^{-1}(\mathrm{P}<0,05)$. Penggunaan pipa mikropori sebagai diffuser aerasi juga dapat meningkatkan rasio konversi pakan dan retensi protein lebih tinggi dibandingkan menggunakan batu aerasi $(\mathrm{P}<0,05)$.
\end{abstract}

\section{Abstract}

Biofloc technology can improve water quality in intensive catfish culture and also can be used as feed for fish. However, the high oxygen demand of heterotrophic bacteria results in the dissolved oxygen in the media is relatively low so that it 
can inhibit the fish growth. This study was conducted to evaluate several microporous diffuser designs in intensive catfish culture based on biofloc technology. Completely Randomized Design (CRD) was used; it consists of four treatments and three replications. Micropore pipes were formed in several shapes in the biofloc system, namely: linear (BFT L), circular (BFT S), and parallel (BFT P). Airstone used as a control (BFT K). The results showed the use of a microporous pipe produced more high dissolved oxygen in the range of $3-5.7 \mathrm{mg} / \mathrm{l}$. The highest survival rate for catfish is $78,67 \%$ at BFT L $(\mathrm{P}<0.05)$. The highest specific growth rate was found in BFT L and BFT S (6.80\%/day and 6.68\%/day). The use of micro-porous pipes as aeration diffuser can also increase the feed conversion ratio and protein retention higher than that of the airstone $(\mathrm{P}<0.05)$.

\section{PENDAHULUAN}

Ikan lele (Clarias gariepinus) merupakan komoditas perikanan yang memiliki potensi bisnis yang baik dan memiliki keunggulan antara lain yaitu pertumbuhan yang pesat, mampu menyesuaikan dengan lingkungan pemeliharaan serta dapat dibudidayakan secara massal. Namun, kendala dalam budidaya ikan lele adalah biaya pakan yang tinggi sehingga margin keuntungan yang diperoleh relatif rendah. Untuk itu, diperlukan solusi yang tepat guna untuk meningkatkan efisiensi budidaya ikan lele secara intensif.

Prinsip budidaya intensif yaitu pemeliharaan ikan dengan padat tebar yang tinggi dan ikan diberi pakan buatan yang mengandung protein tinggi. Namun demikian, proses metabolisme protein pakan menghasilkan produk ekskresi dalam bentuk amonia, residu pakan dan feses (Allsopp et al., 2008). Pada waktu yang sama bakteri akan memineralisasi sisa pakan yang terbuang dan juga feses menjadi amonia, sehingga semakin tinggi kepadatan ikan yang dibudidayakan, maka limbah amonia akan semakin meningkat pada wadah pemeliharaan. Amonia bersifat toksik terhadap ikan meskipun pada konsentrasi yang rendah (Wedemeyer, 1996; Ren et al., 2016).

Pada teknologi bioflok amonia akan dimanfaatkan oleh bakteri heterotrof untuk disintesis menjadi protein bakteri yang selanjutnya menjadi bioflok. Adanya bioflok pada wadah pemeliharaan memberikan keuntungan yaitu kualitas air terjaga dengan baik, dan bioflok juga dapat dimanfaatkan sebagai pakan tambahan bagi ikan budidaya (Avnimelech, 1999).

Kelemahan teknologi bioflok antara lain adalah adanya kebutuhan oksigen yang sangat banyak. Bakteri heterotrof penyusun bioflok membutuhkan oksigen sebesar 4,71 g untuk mengonversi setiap 1 gram $\mathrm{N}_{-} \mathrm{NH}_{4}$ (Ebeling et al., 2006). Hal ini menyebabkan kandungan oksigen terlarut pada wadah pemeliharaan ikan relatif rendah hingga mencapai $1,5-2 \mathrm{mg} / \mathrm{l}$. Sementara itu, ikan lele yang dipelihara pada level oksigen terlarut kurang dari 1,5 $\mathrm{mg} / \mathrm{l}$ menyebabkan nafsu makan ikan lele berkurang dan akan berdampak pada menurunnya hasil panen. Untuk itu, kecukupan kebutuhan oksigen terlarut yang optimal sangat dibutuhkan agar dapat mendukung pertumbuhan ikan dengan baik. Boyd dan Tucker (1998) menyatakan bahwa untuk menunjang pertumbuhan ikan dibutuhkan kandungan oksigen terlarut di atas $5 \mathrm{mg} / \mathrm{l}$.

Oksigen terlarut dapat dihasilkan melalu metode yang umum dipakai yaitu agitasi permukaan air (kincir) dan difusi udara melalui diffuser aerator (batu aerasi) (Bewtra dan Mavinic, 1978). Metode kerja diffuser dan aerasi yaitu dengan memaksa udara melalui media berpori yang menghasilkan gelembung 
dengan jumlah banyak (Endo et al., 2008). Tujuan aerasi adalah membuang gas yang berbahaya seperti $\mathrm{N}_{2}$ dan $\mathrm{CO}_{2}$ dan untuk meningkatkan konsentrasi oksigen terlarut dalam air (Lekang, 2019). Penerapan teknologi gelembung mikro dengan menggunakan pipa mikropori sebagai sistem aerasi menghasilkan jumlah gelembung yang lebih banyak sehingga meningkatkan kandungan oksigen terlarut yang lebih tinggi dibanding batu aerasi coarse diffusers (Supriyono et al., 2016).

Hidayat et al. (2016) menyatakan bahwa pemeliharaan ikan Patin Pasupati dengan menggunakan diffuser aerasi pipa mikropori memiliki pertumbuhan dan kelangsungan hidup yang tinggi. Berdasarkan hal tersebut, untuk meningkatkan produksi dan efisiensi, maka diperlukan suatu kajian ilmiah mengenai penggunaan pipa mikropori pada budidaya ikan lele intensif berbasis teknologi bioflok.

\section{METODOLOGI}

\section{Materi Penelitian}

Material penelitian yang digunakan yaitu drum plastik diameter $180 \mathrm{~cm}$ dengan tinggi $46 \mathrm{~cm}$ sebanyak 12 unit, drum fiber volume 100 liter 1 buah, blower, timbangan digital. Pipa mikropori yang digunakan didatangkan dari Tiongkok, Tianjin Zeguang Rubber and Plastic Products Co., Ltd, dengan spesifikasi diameter pipa mikropori $16 \mathrm{~mm}$ dan diameter dalam $10 \mathrm{~mm}$. Peralatan kualitas air yang digunakan yaitu $\mathrm{pH}$ meter (pHep Hanna), DO meter (Lutron DO-5519), termometer, alat ukur volume flok (tabung sentrifuse $50 \mathrm{ml}$ ). Total amonia nitrogen (TAN), nitrit, nitrat, dan alkalinitas, diukur merujuk pada metode APHA (1998).

Benih ikan lele yang digunakan berukuran 4-5 cm, tapioka sebagai sumber karbon, pakan pelet komersial, dan probiotik (Sanolife Pro-W) dari INVE Belgia dengan kandungan strain Bacillus subtilis dan Bacillus licheniformis.

\section{Rancangan Penelitian}

Rancangan percobaan yang digunakan adalah rancangan acak lengkap (RAL) yang terdiri dari 4 perlakuan dan 3 ulangan. Penerapan perlakuan yaitu bentuk atau model diffuser pipa mikropori, yaitu diffuser bentuk linear (L) pada sistem bioflok (BFT L), diffuser bentuk sirkuler (BFT S), diffuser paralel (BFT P), serta batu aerasi sebagai kontrol (BFT K).
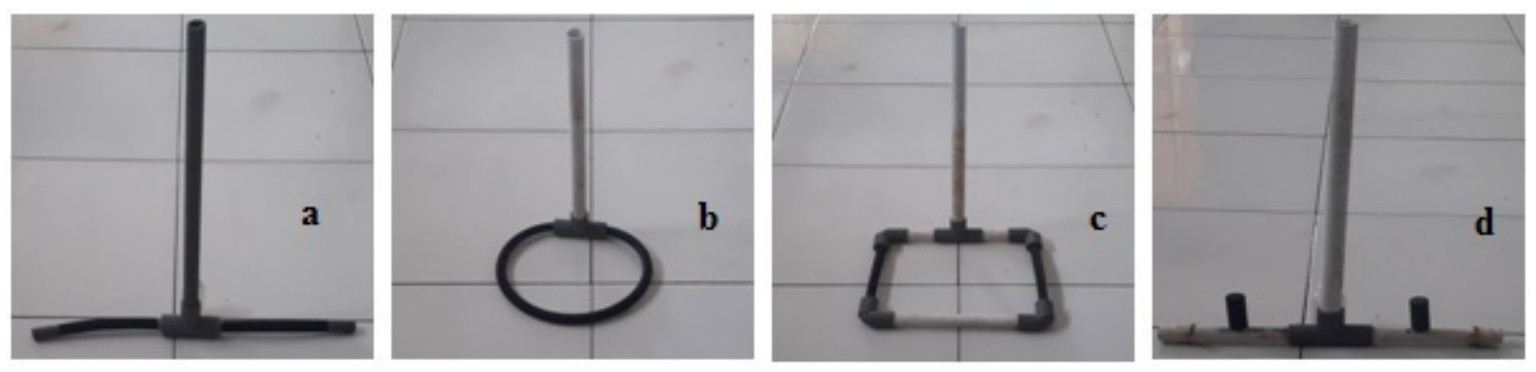

Gambar 1. Bentuk diffuser pipa mikropori. Keterangan : (a) Linear, (b) Sirkuler, (c) Paralel, (d) Kontrol.

\section{Prosedur Kerja}

Wadah penelitian dibersihkan dan kemudian diisi air sehingga didapatkan volume air sebesar 50 liter yang selanjutnya disterilisasi menggunakan klorin dosis 15 ppm. Kemudian diaerasi kuat selama 2-3 hari hingga bau klorin hilang. Penumbuhan flok dilakukan pada semua perlakuan dengan menambahkan probiotik ke dalam wadah pemeliharaan sebagai inokulum biomassa bakteri. Sumber $\mathrm{N}$ untuk menumbuhkan flok adalah $\mathrm{NH}_{4} \mathrm{Cl}$ sebesar 0,5 g/l, dan sebagai sumber karbon menggunakan tepung tapioka dengan estimasi rasio $\mathrm{C} / \mathrm{N}$ target sebesar 10. Selama \pm 7 hari media 
pemeliharaan diaerasi hingga flok terbentuk dan TAN mencapai $0 \mathrm{mg} / \mathrm{l}$ (Sumitro, 2017). Setelah tumbuh flok pada media pemeliharaan, ikan ditebar dengan kepadatan 50 ekor per wadah. Organisme uji yaitu ikan lele dengan ukuran panjang tubuh kisaran $4-5 \mathrm{~cm}$ yang telah diseleksi dengan baik yaitu tidak cacat fisik dan bebas penyakit.

Ikan dipelihara dalam periode 56 hari dan diberi pakan dengan kandungan protein sebesar 30\%. Frekuensi pemberian pakan 3 kali dalam sehari yaitu pagi jam 07.00 WITA, sore jam 15.00 WITA, dan malam jam 23.00 WITA. Pakan diberikan secara ad satiation (sekenyangnya) hingga minggu ke-4, dan memasuki minggu ke-5 dilakukan pemberian pakan sebesar $5 \%$ dari bobot tubuh.

Tepung tapioka dengan kadar karbon $40 \%$ ditambahkan setiap dua hari dengan estimasi rasio $\mathrm{C} / \mathrm{N}$ target 10 yang merujuk pada metode Avnimelech (1999). Selama periode penelitian, ikan dipuasakan sekali dalam seminggu selama 24 jam. Pada bulan pertama periode penelitian endapan flok dibuang setiap 2 hingga 3 hari yang disesuaikan dengan pengaturan kepadatan volume flok maksimal $80 \mathrm{ml} / \mathrm{l}$.

Pengambilan sampel dalam penelitian ini berupa contoh air dan ikan yang diamati setiap 14 hari. Contoh ikan diambil untuk dilakukan pengukuran bobot individu ikan. Pengambilan contoh ikan untuk analisis retensi protein diamati saat permulaan dan akhir penelitian. Pada akhir pemeliharaan, ikan dihitung dan ditimbang untuk diketahui jumlah ikan yang hidup dan juga pertumbuhan.

Laju pertumbuhan harian (LPH) diukur dengan rumus yang dikemukakan Huisman (1987):

$\alpha=[\sqrt[t]{W t / W 0}-1] \times 100$

Keterangan :

a $\quad$ : Laju pertumbuhan harian $\left(\%\right.$ hari $\left.^{-1}\right)$

$\mathrm{W}_{\mathrm{t}}$ : Bobot rata-rata ikan akhir pemeliharaan (g)

$\mathrm{W}_{0}$ : Bobot rata-rata ikan awal pemeliharaan (g)

t : Lama pemeliharaan (hari)
Rasio konversi pakan (RKP) dihitung sesuai rumus dari Goddard (1996) :

$\mathrm{RKP}=\frac{\mathrm{F}}{\mathrm{Wt}+\mathrm{Wd}-\mathrm{Wo}_{\mathrm{o}}}$

Keterangan :

RKP : Rasio konversi pakan

$\mathrm{F} \quad$ : Jumlah pakan yang diberikan $(\mathrm{kg})$

$\mathrm{W}_{\mathrm{t}}$ : Biomassa ikan pada akhir pemeliharaan $(\mathrm{kg})$

$\mathrm{W}_{\mathrm{d}}$ : Biomassa ikan mati selama pemeliharaan $(\mathrm{kg})$

$\mathrm{W}_{0} \quad$ : Biomassa ikan pada awal pemeliharaan $(\mathrm{kg})$

Retensi protein dihitung menggunakan rumus Watanabe (1988) :

$\mathrm{RP}=\frac{\mathrm{Pt}-\mathrm{Po}}{\mathrm{Kp}} \times 100$

Keterangan :

RP : Retensi protein (\%)

$\mathrm{P}_{\mathrm{t}}$ : Jumlah protein pada akhir pemeliharaan $(\mathrm{g})$

$\mathrm{P}_{0} \quad$ : Jumlah protein pada awal pemeliharaan (g)

$\mathrm{K}_{\mathrm{p}}$ : Jumlah protein pakan yang konsumsi (g)

\section{Analisis Data}

Data hasil pengamatan parameter kinerja produksi dianalisis ragam (ANOVA) menggunakan program SPSS 21.1 pada selang kepercayaan 95\%. Jika hasilnya berbeda nyata, akan dilanjutkan menggunakan uji Tukey. Data pengukuran parameter air yaitu suhu, oksigen terlarut, $\mathrm{pH}$, TAN, nitrit, nitrat, dan volume flok dianalisis secara deskriptif.

\section{HASIL DAN PEMBAHASAN}

\section{Kualitas Air}

Hasil pengukuran oksigen terlarut menunjukkan hasil yang fluktuatif pada semua perlakuan. Namun, kandungan oksigen terlarut yang dihasilkan pada semua perlakuan pipa mikro-pori lebih tinggi dibandingkan dengan kontrol (BFT K). Menurut Supriyono et al. (2016), pipa mikropori menghasilkan diameter gelembung yang lebih kecil dibanding batu aerasi. Diameter gelembung yang kecil mampu meningkatkan luas permukaan air yang berimpitan dengan udara sehingga mempermudah proses 
difusi udara ke air dan meningkatkan kelarutan oksigen (Navisa et al., 2014). Hasil pengukuran suhu selama penelitian berkisar $26-29^{\circ} \mathrm{C}$ dan masih dalam kisaran yang baik untuk ikan lele.

Nilai TAN, nitrit, dan nitrat relatif tidak berbeda antar perlakuan. Konsentrasi TAN dan nitrit yang bersifat toksik untuk ikan masih di bawah batas maksimum yang dapat ditoleransi oleh ikan meskipun dengan kepadatan yang tinggi. Nilai TAN, nitrit dan nitrat yang diperoleh selama penelitian memiliki nilai yang lebih kecil dibandingkan hasil yang diperoleh Sumitro (2017), dengan nilai TAN berkisar 0,01-0,7 mg/l, nitrit 0,02$0,5 \mathrm{mg} / \mathrm{l}$, dan nitrat $0,3-0,9 \mathrm{mg} / 1$ pada budidaya lele intensif berbasis teknologi bioflok. Hasil ini membuktikan bahwa bioflok dapat menjaga kualitas air. Ekasari (2009) menyatakan bahwa teknologi bioflok memiliki prinsip utama yaitu memperbaiki kualitas air menggunakan bakteri heterotrof yang dapat memanfaatkan nitrogen organik dan nitrogen anorganik yang toksik dalam air.

Nilai pH pada masing-masing perlakuan relatif tidak berbeda dan masih pada kisaran yang mendukung pertumbuhan lele. Nilai alkalinitas pada penelitian ini menunjukkan nilai kisaran 55,26 - 73,25 mg/l dan masih mendukung untuk budidaya ikan lele. Menurut Boyd dan Tucker (1998), kisaran alkalinitas yang sesuai pada budidaya lele adalah 30 $500 \mathrm{mg} / \mathrm{l}$. Pada penelitian ini dilakukan pengaturan volume flok dengan cara membatasi volume flok maksimal $80 \mathrm{ml} / \mathrm{l}$ melalui pembuangan endapan flok secara teratur. Hal ini dilakukan untuk mengontrol konsumsi oksigen oleh biomassa bakteri heterotrof.

Tabel 1. Kisaran kualitas air pada pemeliharaan ikan lele sistem bioflok dengan bentuk diffuser aerasi yang berbeda selama 8 minggu masa pemeliharaan.

\begin{tabular}{lcccc}
\hline \multirow{2}{*}{ Parameter } & \multicolumn{4}{c}{ Perlakuan (Bentuk diffuser) } \\
& $($ BFT L) & (BFT S) & (BFT P) & (BFT K) \\
\hline Oksigen terlarut (mg/l) & $3-5,24$ & $3-5,7$ & $3-4,82$ & $3-4,76$ \\
Suhu $\left({ }^{\circ} \mathrm{C}\right)$ & $26-29$ & $26-29$ & $26-29$ & $26-29$ \\
TAN $(\mathrm{mg} / \mathrm{l})$ & $0,007-0,027$ & $0,004-0,022$ & $0,005-0,032$ & $0,004-0,018$ \\
Nitrit $(\mathrm{mg} / \mathrm{l})$ & $0,016-0,024$ & $0,026-0,034$ & $0,028-0,048$ & $0,014-0,03$ \\
Nitrat $(\mathrm{mg} / \mathrm{l})$ & $0,037-0,046$ & $0,039-0,047$ & $0,0321-0,042$ & $0,034-0,044$ \\
pH & $6-7,7$ & $6-7,5$ & $6-7,9$ & $6-7,8$ \\
Alkalinitas (mg/l) & $57,82-65,53$ & $60,39-62,96$ & $68,10-73,25$ & $55,26-65,54$ \\
Volume flok (mg/l) & $40-80$ & $40-80$ & $40-80$ & $40-80$ \\
\hline
\end{tabular}

\section{Kinerja Produksi}

Nilai tingkat kelangsungan hidup (TKH) terbaik terdapat pada perlakuan BFT L sebesar 78,67\%, diikuti perlakuan BFT S sebesar 76,67 \%, BFT P sebesar 74,67\%, dan terendah BFT $\mathrm{K}$ sebesar $67,33 \%(\mathrm{P}<0,05)$. Hasil ini menunjukkan bahwa penggunaan pipa mikropori sebagai diffuser aerasi mampu meningkatkan kelangsungan hidup ikan lele dibanding kontrol (batu aerasi) pada sistem bioflok. Kematian ikan pada perlakuan kontrol diduga disebabkan oleh bakteri dengan gejala yang mirip serangan bakteri Aeromonas hydrophila, yaitu tanda-tanda seperti luka pada kulit dan rusaknya sirip ekor, pendarahan pada insang dan anus (Prayogi et al., 2016; Rejeki et al., 2016).

Kandungan oksigen terlarut pada perlakuan mikropori yang lebih tinggi diduga dapat meningkatkan status kesehatan ikan selanjutnya meningkatkan kelangsungan hidup ikan lele. Hidayat et al. (2016) melaporkan bahwa penggunaan pipa mikropori dapat 
meningkatkan kelangsungan hidup pada budidaya ikan patin sebesar $97,22 \%$, dan $33,33 \%$ yang menggunakan batu aerasi.

Tabel 2. Kinerja produksi pada pembesaran lele sistem bioflok menggunakan diffuser yang berbeda selama 8 minggu masa pemeliharaan.

\begin{tabular}{ccccc}
\hline \multirow{2}{*}{ Kinerja Produksi } & \multicolumn{4}{c}{ Perlakuan (Bentuk diffuser) } \\
& (BFT L) & (BFT S) & (BFT P) & $($ BFT K) \\
\hline TKH (\%) & $78,67 \pm 0,15^{\mathrm{a}}$ & $76,67 \pm 0,15^{\mathrm{ab}}$ & $74,67 \pm 0,15^{\mathrm{b}}$ & $67,33 \pm 0,15^{\mathrm{c}}$ \\
LPH (\%//hari) & $6,80 \pm 3,97^{\mathrm{a}}$ & $6,68 \pm 2,73^{\mathrm{a}}$ & $6,67 \pm 0,11^{\mathrm{a}}$ & $5,99 \pm 0,48^{\mathrm{b}}$ \\
Biomassa (kg) & $3,24 \pm 3,10^{\mathrm{a}}$ & $3,13 \pm 2,08^{\mathrm{a}}$ & $2,86 \pm 3,20^{\mathrm{b}}$ & $2,18 \pm 1,42^{\mathrm{c}}$ \\
RKP & $0,81 \pm 0,06^{\mathrm{a}}$ & $0,89 \pm 0,02^{\mathrm{ab}}$ & $0,83 \pm 0,08^{\mathrm{a}}$ & $0,92 \pm 0,22^{\mathrm{b}}$ \\
RP (\%) & $59,99 \pm 4,63^{\mathrm{a}}$ & $59,06 \pm 1,72^{\mathrm{a}}$ & $55,14 \pm 5,78^{\mathrm{ab}}$ & $44,27 \pm 6,63^{\mathrm{b}}$ \\
\hline
\end{tabular}

Penerapan diffuser aerasi pipa mikropori pada pemeliharaan ikan lele sistem bioflok dapat menghasilkan pertumbuhan harian yang lebih tinggi dibandingkan kontrol $(\mathrm{P}<0,05)$. Hal ini diduga karena oksigen terlarut yang dihasilkan oleh pipa mikropori lebih tinggi daripada perlakuan batu aerasi sehingga dapat meningkatkan metabolisme ikan. Laju metabolisme sangat dipengaruhi oleh konsentrasi oksigen di lingkungan pemeliharaan. Peningkatan oksigen terlarut dapat meningkatkan konversi protein dan nutrien lainnya menjadi energi untuk pertumbuhan (Welker et al., 2013). Mallya (2007) menyatakan ketika konsentrasi oksigen terlarut berkurang menyebabkan aktivitas respirasi dan makan juga berkurang. Akibatnya, pertumbuhan ikan menjadi lambat.

Nilai biomassa ikan akhir tertinggi terdapat pada perlakuan BFT L sebesar 3,24 kg dan BFT S sebesar 3,13 kg, sedangkan biomassa ikan akhir paling rendah yaitu BFT K sebesar 2,18 kg. Hal ini menunjukkan bahwa pemeliharaan ikan lele sistem bioflok menggunakan diffuser aerasi pipa mikropori lebih efisien karena menghasilkan peningkatan biomassa ikan lele yang lebih besar.

Rasio konversi pakan pada perlakuan BFT L sebesar 0,81 dan BFT P 0,83 lebih rendah dibandingkan kontrol yaitu $0,92(\mathrm{P}<0,05)$. Nilai RKP sebesar 0,81 berarti dengan jumlah pakan sebesar $0,81 \mathrm{~kg}$ dapat meningkatkan sebesar $1 \mathrm{~kg}$ bobot ikan. Selain meningkatkan pertumbuhan, penggunaan pipa mikropori pada sistem bioflok juga lebih efisien dalam penggunaan pakan. Hasil ini membuktikan bahwa kandungan oksigen yang lebih tinggi pada perlakuan diffuser mikropori mampu dimanfaatkan oleh ikan untuk metabolisme dengan optimal yang akhirnya menghasilkan FCR yang baik.

Hasil retensi protein menunjukkan diffuser mikropori mampu meningkatkan retensi protein lebih tinggi (59,0659,99\%) dibanding kontrol (44,27\%) $(\mathrm{P}<0,05)$. Hasil ini menunjukkan ikan lele yang dipelihara menggunakan diffuser pipa mikropori dapat memanfaatkan flok lebih optimal sehingga flok digunakan untuk sintesis protein tubuh. Selain itu, tersedianya kandungan oksigen terlarut yang tinggi pada media budidaya diffuser pipa mikropori diduga meningkatkan konsumsi oksigen ikan yang selanjutnya meningkatkan sintesis protein. Smith dan Houlihan (1995) menyatakan bahwa 80 hingga $87 \%$ dari konsumsi oksigen pada ikan digunakan untuk sintesis protein.

\section{UCAPAN TERIMA KASIH}

Kami mengucapkan terima kasih kepada semua pihak yang membantu dalam penyelesaian penelitian ini. 


\section{KESIMPULAN}

Aplikasi desain pipa mikro-pori berbentuk linear (L) sebagai diffuser aerasi pada budidaya ikan lele sistem bioflok merupakan perlakuan terbaik karena mampu menjaga kualitas air dalam kondisi optimal sehingga menghasilkan kelangsungan hidup, pertumbuhan, rasio konversi pakan serta retensi protein yang lebih tinggi selama pemeliharaan.

\section{DAFTAR PUSTAKA}

Allsopp, M., Johnston, P. dan Santillo, D., 2008. Challenging the aquaculture industry on sustainability: Technical overview. Greenpeace Research Laboratories Technical, Washington. http://www.greenpeace.to/publicat ions/aquaculture_report_technical. pdf.

APHA, 1998. Standard methods for the examination of the water and wastewater. American public health association. Washington DC.

Avnimelech, Y., 1999. Carbon/nitrogen ratio as a control element in aquaculture systems. Aquaculture, 176(3-4), pp.227-235. https://doi. org/10.1016/S0044-8486(99) 00085-X.

Bewtra, J.K. dan Mavinic, D.S., 1978. Diffused aeration systems from theory to design. Canadian Journal of Civil Engineering, 5(1), pp.32-41. 10.1139/178-005

Boyd, C.E. dan Tucker, C.S., 1998. Pond aquaculture water quality management. Springer Science \& Business Media. 10.1007/978-14615-5407-3

Ebeling, J.M., Timmons, M.B. dan Bisogni, J.J., 2006. Engineering analysis of the stoichiometry of photoautotrophic, autotrophic, and heterotrophic removal of ammonianitrogen in aquaculture systems. Aquaculture, 257(1-4), pp.346-358. https://doi.org/10.1016/j.aquacult ure.2006.03.019

Ekasari, J., 2009. Teknologi bioflok: Teori dan aplikasi dalam perikanan budidaya sistem intensif. Jurnal Akuakultur Indonesia, 8(2), pp.117126. https://doi.org/10.19027/jai. 8.117-126

Endo, A., Srithongouthai, S., Nashiki, H., Teshiba, I., Iwasaki, T., Hama, D. dan Tsutsumi, H., 2008. DOincreasing effects of a microscopic bubble generating system in a fish farm. Marine pollution bulletin, 57(1-5), pp.78-85. https://doi.org/ 10.1016/j.marpolbul.2007.10.014

Goddard, S., 1996. Feed management in intensive aquaculture. Chapman and Hall. New York. 10.1007/978-14613-1173-7.

Hidayat, K.W., Supriyono, E., Setiyanto, D.D. dan Widiyati, A., 2016. Effect of three simple design micro-pore aeration on growth and survival of hybrid catfish Pangasius sp. International Journal of Fisheries and Aquatic Studies, 4(4), pp.170-172. http://www.fisheriesjournal.com/a rchives/2016/vol4issue4/PartC/43-3-679.pdf

Huisman, E.A., 1987. Principles of fish production. Department of Fish Culture and Fisheries, Wageningen Agriculture University, pp.1-170.

Lekang, O.I., 2019. Aquaculture engineering. Hoboken, John Wiley \& Sons.

Mallya, Y.J., 2007. The effects of dissolved oxygen on fish growth in aquaculture. The United Nations University Fisheries Training Programme, Final Project. https:// www.grocentre.is/static/gro/public ation/58/document/yovita07prf.pd f.

Navisa, J., Sravya, T., Swetha, M. dan Venkatesan, M., 2014. Effect of bubble size on aeration process. Asian Journal of Scientific Research, 7(4), pp.482-487. 10.3923/ajsr. 2014.482 .487

Prayogi, Y.T., Kusdarwati, R. dan Kismiyati, K., 2016. Isolasi, Identifikasi Dan Presentasi Ikan Lele Dumbo (Clarias gariepinus) yang Terinfeksi Bakteri Aeromonas 
hydrophila yang Dipelihara di Keramba Jaring Apung Di Bozem Moro Krembangan, Surabaya. Journal of Aquaculture and Fish Health, 5(2), pp.64-69. http://dx. doi.org/10.20473/jafh.v5i2.11324.

Rejeki, S., Triyanto, T. dan Murwantoko, M., 2016. Isolation and Identification of Aeromonas spp. from Diseased African Catfish (Clarias sp.) in Ngawi Regency. Jurnal Perikanan Universitas Gadjah Mada, 18(2), pp.55-60. https://doi. org/10.22146/jfs.26917

Ren, Q., Li, M., Yuan, L., Song, M., Xing, X., Shi, G., Meng, F. dan Wang, R., 2016. Acute ammonia toxicity in crucian carp Carassius auratus and effects of taurine on hyperammonemia. Comparative Biochemistry and Physiology Part C: Toxicology \& Pharmacology, 190, pp.9-14. https://doi.org/10.1016/j. cbpc.2016.08.001.

Smith, R.W. dan Houlihan, D.F., 1995. Protein synthesis and oxygen consumption in fish cells. Journal of Comparative Physiology B, 165(2), pp.93-101. https://doi.org/10.1007 /BF00301473

Sumitro, 2017. Kinerja Produksi dan Keseimbangan Massa Nitrogen dalam Budidaya Ikan Lele Clarias gariepinus intensif berbasis teknologi bioflok. Tesis. Institut Pertanian Bogor. https://repository. ipb.ac.id/handle/123456789/8424 9.

Supriyono, E., Hidayat, K.W., Djokosetiyanto, D. dan Widiyati, A., 2016. The use of rubber microporous tubing as an aeration diffuser and the effect on blood gas in hybrid catfish Pangasius sp. Aquaculture, Aquarium, Conservation \& Legislation, 9(6), pp.1294-1300. http://www.bioflux. com.ro/docs/2016.1294-1300.pdf

Watanabe, T., 1988. Fish Nutrition and Mariculture, JICA Textbook the General Aquaculture Course. Tokyo:
Kanagawa International Fish Training Center.

Wedemeyer, G., 1996. Physiology of fish in intensive culture systems. Springer Science \& Business Media. 10.1007/978-1-4615-6011-1.

Welker, A.F., Moreira, D.C., Campos, É.G. dan Hermes-Lima, M., 2013. Role of redox metabolism for adaptation of aquatic animals to drastic changes in oxygen availability. Comparative Biochemistry and Physiology Part A: Molecular \& Integrative Physiology, 165(4), pp.384-404. 10.1016/j. cbpa.2013.04.003. 